\title{
Extending Shelf-life of Different Cut-flowers under Cold Room Conditions
}

\author{
Dr. Parag Babaji Jadhav \\ Agricultural Research Expert, Ecofrost Technologies Pvt. Ltd., Survey No 134/1, 134/2,130/3, Jeevan Nagar, Tathawade, \\ Pune, Maharashtra- 411033. \\ Corresponding author email ID: parag @ecozensolutions.com and contact no +91-7767069974.
}

\begin{abstract}
Uniform and healthy Rose cv. 'Dutch'; Gerbera cv. 'Lexington'; Gladiolus cv. 'Top Secrate'; Tuberose cv. 'Bizet' and Carnation cv. 'Liberty' were used for the study in September 2016. Cut flowers were harvested at $7.00 \mathrm{am}$ at proper stage, transported within 1.30 hours by AC car to the Agricultural Research Laboratory of Ecofrost Technologies Pvt. Ltd., Pune and then immediately prepared for post-harvest treatment and storage. The aim of this study was to determine the effectiveness of different storage conditions, i.e. room and cold storage conditions $\left(10^{\circ} \mathrm{C}+93 \% \mathrm{RH}\right)$ on the longevity of the cut flowers. The two treatments viz., holding flowers at room temperature $(R T)\left(T_{1}\right)$ and at cold room conditions $\left(T_{2}\right)$, were replicated twice. The result showed that keeping cut-flowers at cold storage in a holding-solution of tap water recorded the maximum storage-life (days) compared to room conditions.
\end{abstract}

Keywords- Rose, Gerbera, Gladiolus, Tuberose, Carnation, Storage-life, Ecofrost.

\section{INTRODUCTION}

Cut-flowers are often harvested at the horticultural stage, so flowers need a large amount of soluble carbohydrates for proper opening and long life. Treatment with sugars, such as Sucrose and Glucose in combination with some germicides/biocides extend the vase-life of many cut flowers and can affect ethylene production and upregulation of sugars accumulated in floral organs (Ichimura et al., 2006).

While production of high-quality flowers is important, it is critical to handle the flowers properly after they are harvested from the field. There are reports which suggest that improper post-harvest handling accounts for 20 to $30 \%$ of cut-flower loss during marketing (Jadhav et al., 2014).

The objective of this study was to determine the effect of different storage conditions like room conditions and cold room on the storage-life of Rose cv. 'Dutch'; Gerbera cv. 'Lexington'; Gladiolus cv. 'Top Secrate'; Tuberose cv. 'Bizet' and Carnation cv. 'Liberty'.

\section{MATERIAL AND METHODS}

The present study was carried out in the Agri Research Laboratory of Ecofrost Technologies Pvt. Ltd. Tathawade, Pune (MH), India in September 2016. Rose cv. 'Dutch'; Gerbera, Lexington; Gladiolus, Top Secrate; Tuberose, Bizet; and Carnation, Liberty flowers were cut in the early morning of $19^{\text {th }}$ September 2016. After transportation, stems of cut-flowers of different flower crops were trimmed in the laboratory except Gerbera. Almost all cutflowers had different stem lengths. Cut-flowers were put immediately in tap water containing 5\% sucrose with Silver Thiosulphate (STS) @ 200 ppm for 4 hours under room conditions. Cut flowers $\left(\mathrm{T}_{2}\right)$ after postharvest treatment were subjected to cold storage treatment and cutflowers of different flower crops after post-harvest treatment were stored at room conditions $\left(\mathrm{T}_{1}\right)$. Each treatment had two replications (R-2) and ten flowers per replication. After every two days, Rose cv. 'Dutch'; Gerbera, Lexington; Gladiolus, Top Secrate; Tuberose, Bizet and Carnation, Liberty flower stems were checked for fungal infection which could impede water uptake. Then, each flower stem was re-cut under the water to eliminate air bubbles or emboli, which can decrease flower life and lead to premature wilting of the bloom of Rose cv. 'Dutch'; Gladiolus, 'Top Secrate'; Tuberose, 'Bizet' and Carnation, 'Liberty' flowers. Precautions were also taken to remove foliage below the water line to prevent bacterial proliferation. Ten flowers of each crop were treated replication-wise, under post-harvest treatments. The period of initial pre-treatment solution was 4 hours under room conditions. The treated soaked Rose cv. 'Dutch'; Gerbera, 'Lexington'; Gladiolus, 'Top Secrate'; Tuberose, 'Bizet' and Carnation, 'Liberty' flower stems were transferred to a tap-water solution on $19^{\text {th }}$ September 2016 inside cold room $\left(\mathrm{T}_{2}\right)$ and in room conditions $\left(\mathrm{T}_{1}\right)$. The level of the tap water was maintained as 2.5 to $3.0 \mathrm{~cm}$ at the bottom of the bucket.

The storage-life was recorded by observing the number of days that were taken between the time of harvest and end of longevity that occurs in ways such as bending of the floral axis just below the flower head (bent-neck in rose), 
flower closure, wilting or abscission, changing color of petals prior to wilting or abscission.

\section{Observations recorded:}

The observations regarding the post-harvest parameter of the storage-life of Rose cv. 'Dutch'; Gerbera, 'Lexington'; Gladiolus, 'Top Secrate'; Tuberose, 'Bizet' and Carnation, 'Liberty' were recorded for each treatment replicationwise and cumulative data was subjected to analysis.
III.

RESULTS AND DISCUSSIONS

The highest storage life (days) was noticed in Rose cv. 'Dutch'; Gerbera, 'Lexington'; Gladiolus, 'Top Secrate'; Tuberose, 'Bizet' and Carnation, 'Liberty' inside cold room $\left(\mathrm{T}_{2}\right)$ compared to room conditions $\left(\mathrm{T}_{2}\right)$ (Table 1 ; Photo 1 and 2).

Table.1: The storage-life (days) of different cut-flowers at room temperature and inside cold room ( $10^{\circ} \mathrm{C}$ and $\left.93 \% \mathrm{RH}\right)$

\begin{tabular}{llccc}
\hline $\begin{array}{l}\text { Sr. } \\
\text { No. }\end{array}$ & Cut-flowers of different & $\begin{array}{c}\text { Storage-life (days) } \\
\text { crops }\end{array}$ & $\begin{array}{c}\text { Storage-life (days) } \\
\text { inside cold room }\end{array}$ & $\begin{array}{c}\text { Post-storage life (days) at } \\
\text { room conditions }\end{array}$ \\
\hline 1 & Rose, 'Dutch' & 3.5 & 5.5 & 1.0 \\
2 & Gerbera, 'Lexington' & 3.0 & 5.0 & 1.0 \\
3 & Gladiolus, 'Top Secrate' & 4.0 & 5.5 & 1.0 \\
4 & Tuberose, 'Bizet' & 4.0 & 5.5 & 1.0 \\
5 & Carnation, 'Liberty' & 4.0 & 5.5 & 1.0 \\
\hline
\end{tabular}

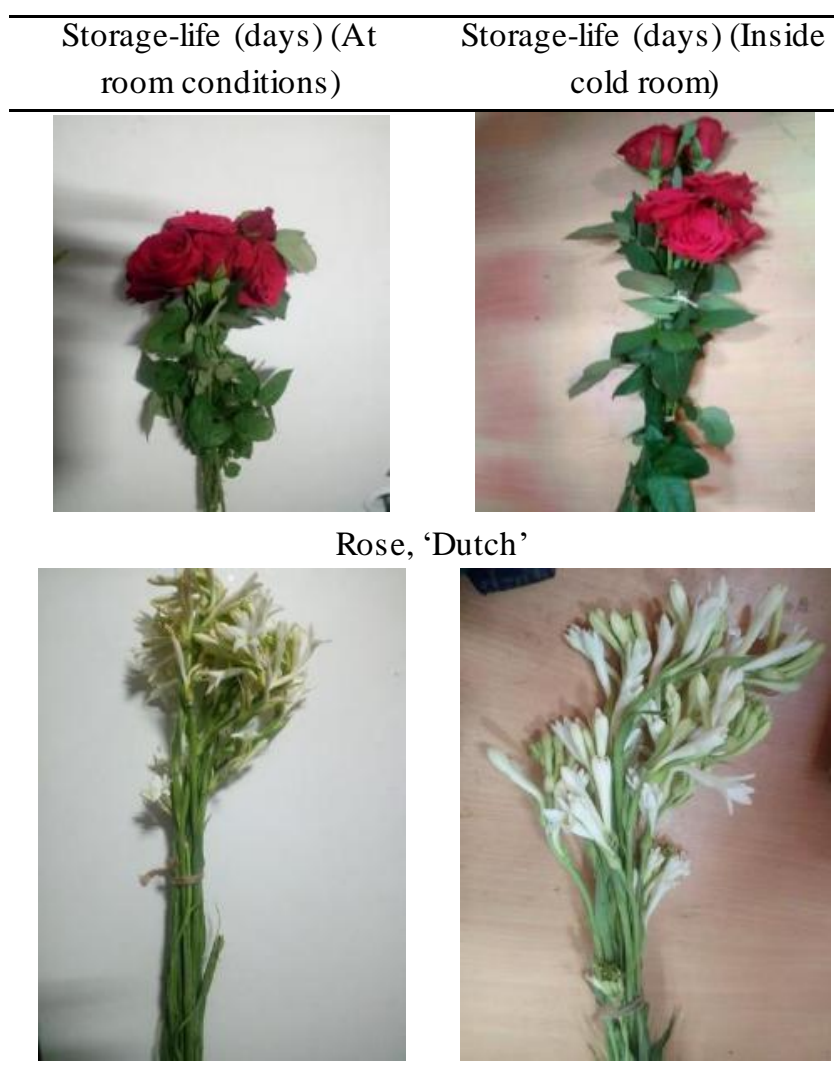

Tuberose, 'Bizet'
Storage-life (days) (At room conditions)

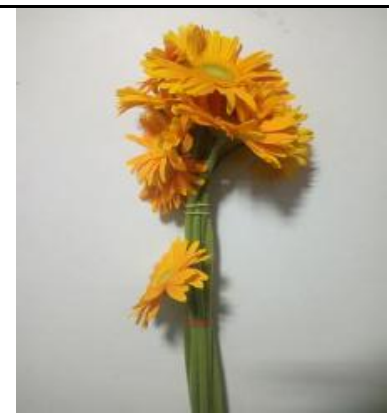

Gerbera, 'Lexington'
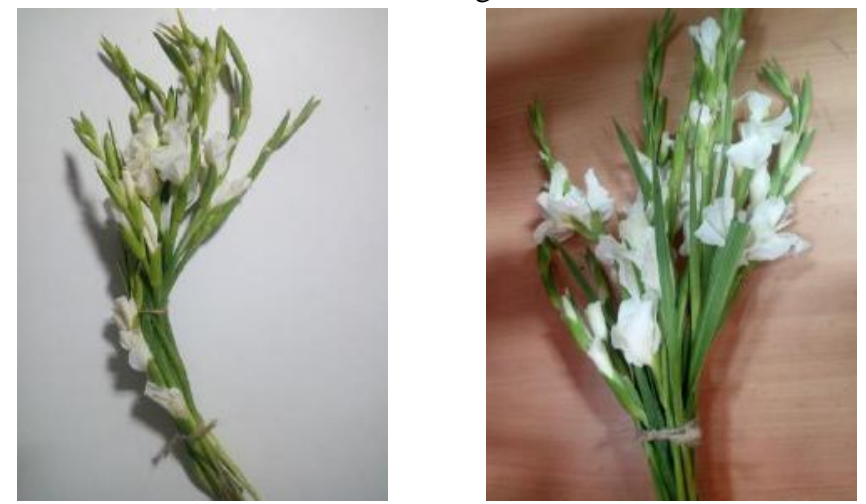

Gladiolus, 'Top Secrate'

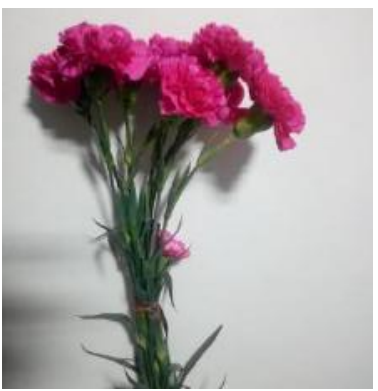

Carnation, 'Liberty'

Photo.1: General view of different cut-flowers after two days storage at room conditions and inside cold room of Ecofrost $\left(10^{\circ} \mathrm{C}\right.$ and $\left.93 \% \mathrm{RH}\right)$. 


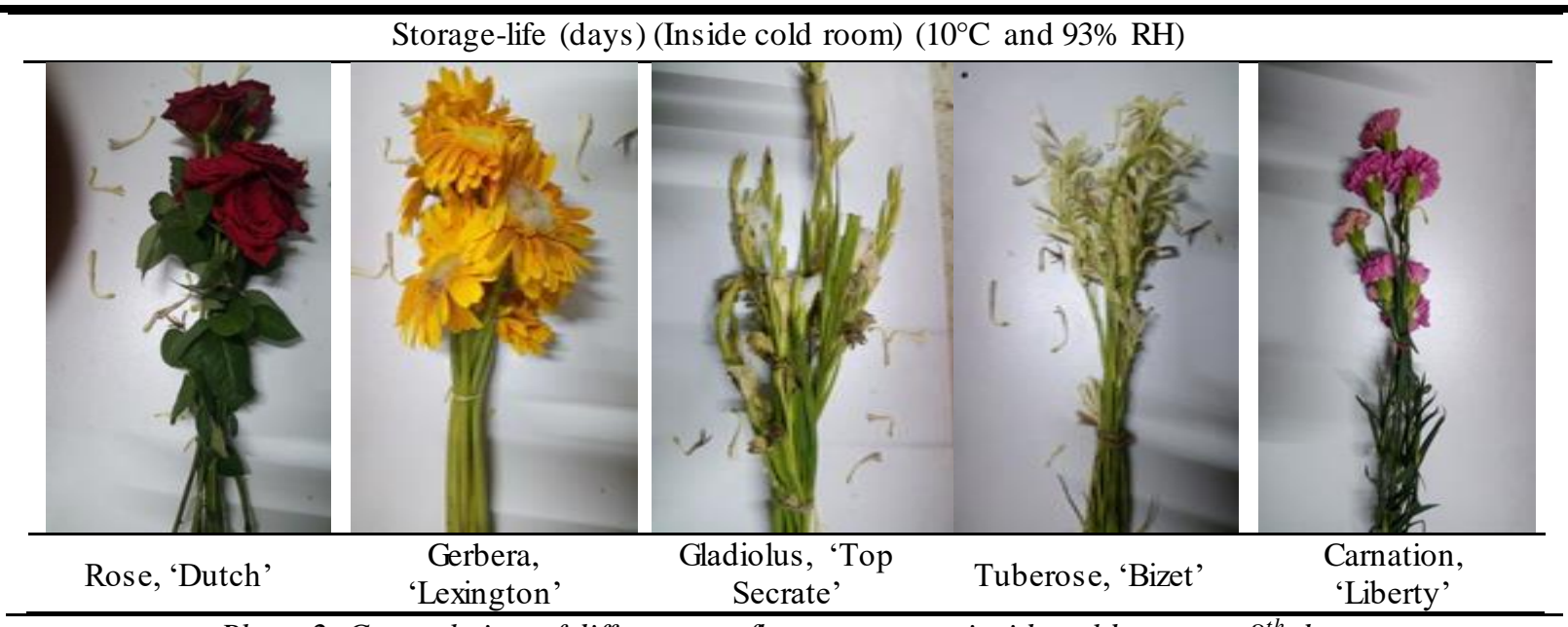

Photo.2: General view of different cut-flowers storage inside cold room on $8^{\text {th }}$ day.

Sucrose serves as a source of energy to make up for the loss of the functioning of leaves and ensures continued development and longevity of the flower. The treatment of cut-flowers with Sucrose was found beneficial in delaying senescence process. When cut flowers are pulsed overnight it results in faster flower opening; longer the stem, longer the vase-life (Jadhav et al., 2014 \& Jadhav et al., 2014). Low temperature was effective in delaying senescence process.

\section{CONCLUSION}

In conclusion, cold storage conditions can extend the life of Rose cv. 'Dutch'; Gerbera, 'Lexington'; Gladiolus, 'Top Secrate'; Tuberose, 'Bizet' and Carnation, 'Liberty' cut-flowers'.

\section{ACKNOWLEDGEMENTS}

The author(s) are grateful to the Directors of Ecofrost Technologies Pvt. Ltd., Survey No 134/1, 134/2,130/3, Jeevan Nagar, Tathawade, Pune, Maharashtra- 411033 for providing facilities for conducting this research.

\section{REFERENCES}

[1] Ichimura, K., Taguchi, M. and Norikoshi, R. (2006). Extension of vase life in cut roses by treatment with Glucose, Isothiazolinonic germicide, Citric Acid and Aluminium Sulphate solution. J. Agri. Res. Quart., 40:263-269.

[2] Jadhav, P. B., Patil, N. B., Dekhane, S. S. and Patel D. J. (2014). Study the effects of different levels of sugar in pulsing treatments on postharvest quality of gladiolus cv. American Beauty. Ann. Bio. Res., 5(8):13-17.

[3] Jadhav, P.B., Senapati, A.K., Patil, N.B., Dekhane, S.S., Harad, N.B. and Patel, D.J. (2014). Effects of different levels of sucrose in vase solution treatments on postharvest solution uptake, florets diameter, vase life of spike of gladiolus cv. American Beauty. Int. J. Infor. Res. Rev., 1(2):1-3. 